\title{
Effects of Mixing Ratio of Heavily Beaten Pinus merkusii Pulp on Physical Properties of Kraft Acacia nilotica Pulp Sheets
}

\author{
Ganis Lukmandaru, Fajar Setiaji, and Rena M. Siagian
}

\begin{abstract}
Paper industries commonly produce pulp sourced from a mixture of pulps, rather than from a single pulp, to obtain desired properties. In addition, the beating process is an essential step with respect to physical properties of pulp. Kraft pine (Pinus merkusii/PM) pulps were beaten to different degrees, i.e 200 300 CSF (heavy-beating) and 300 400 CSF (moderatebeating), paper sheets then were formed from each beaten sample. It was found that the strength properties of prepared paper sheets decreased the longer they were beaten, particularly as seen by the tear index and fold number. By microscopic investigation, it was found that cut or shortened fibers occurred very frequently in the pine pulps. Furthermore, the effects of heavily beaten pine pulp additions on handsheet properties of kraft pulps of Acacia nilotica (AN) were investigated. Four different mixing ratios by weight of AN/PM from 100:0, 90:10, 80:20, and 70:30 during beating, as well as four different kappa numbers of AN pulps $(32.5,34.0,34.2$, and 35.9$)$ were applied. In general, the decrease in strength properties (3 25\%) that occurred with increasing pine pulp ratio was more evident between pulp without pine and a $30 \%$ ratio of pine pulps. Fold number was reduced considerably (2.8 24.7\%) by the blend composition but less pronounced in tear index (3.0 8.9\%) from the initial values. However, the $10 \%$ or $20 \%$ ratio of PM pulps could increase opacity, brightness, and strength properties in some cases. No clear trend was found with increasing kappa number.
\end{abstract}

Keywords: mixture pulp, long fiber, pulp beating, pulp strength, optical properties.

\section{Introduction}

The pulp and paper industry in Indonesia produce mainly mixed tropical hardwood pulps with short fibers. The Acacia mangium wood is one of the preferred raw materials. On the contrary, the source of raw material with long fibers is limited to Pinus merkusii. Therefore, to meet the demand of long fibers, Indonesia is dependent on imports. In view of the high demand on a domestic level for paper and in order to reduce imported pulps, it is necessary to further identify the local fibrous raw materials and evaluate their suitability for pulping. Beside Acacia mangium, Acacia nilotica is a widely distributed species in some areas in Indonesia and is easy to grow. In Baluran National Park, particularly, its presence demonstrates a fast growing and invasive behaviour.

The potentialities of Acacia nilotica (AN) wood were assessed for their suitability for papermaking (Khristova et al. 1997; Lukmandaru et al. 2002; Onuorah et al. 2014). The pulps met the standard for printing-, writing- and wrapping-papers. It was noted that the unbleached pulp of AN wood from Indonesia was still dark (brightness of 15.78 17.13\%) and showed a high kappa number (31.8 36.3) for further bleaching process (Lukmandaru et al. 2002). This suggests that this material would be more suitable for unbleached end-products, such as wrapping papers or kraft-liners.

In the practice, it is necessary to utilize pulp mixtures to improve the specific characteristics of final paper that cannot be obtained by just one type of fiber (Shmulsky and Jones 2011). For years, long fiber pulps have been used to improve both wet and dried strengths in paper in order to increase paper machine runnability (Walker 2006; Nordström and Hermansson 2017). In case of kraft-liners, the mixture consists of strong softwood kraft pulp with long fibers and a relatively weak pulp with short fibers. The pulp mixture is possible in both mixed refined pulps and separately refined pulps (Chauhan et al. 2011; Azeez et al. 2016). It is already known that excessive beating of long fiber pulp is avoided as it deteriorates some physical properties of the resulting paper. However, excessive beating is frequently applied in recycled pulps where cutting or shortening of fibers often occurs. It is thought that mixtures of different pulps would behave additively in paper. Unfortunately, studies with regard to the additional effect of a strong degree of beating/refining of long fiber on pulp handsheets of short fiber pulps are scarce. Thus, this study aims to evaluate the effect of the addition of soft wood i.e. Pinus merkusii pulps prepared by intensive beating to Acacia nilotica kraft pulps on the final paper product's physical properties at a laboratory scale.

\section{Materials and Methods}

\section{Sample Preparation}

The Pinus merkusii (PM) tree (wood SG $=0.57$ ) of 15 years old in this study was taken from Perhutani plantation in Purworejo, Central Java Province whereas Acacia nilotica (AN) tree (wood $S G=0.86, \mathrm{dbh}=25 \mathrm{~cm}$ ) was felled in Baluran National Park, Situbondo, East Java Province. Then, the samples from the bottom parts were chipped manually, to dimensions of $30 \times 30 \times 2 \sim 3 \mathrm{~mm}$ for pulping. 
The wood chips were then air-dried and dry-stored until the initiation of pulping.

\section{Kraft Pulping}

Kraft cooking of AN was performed using a laboratory type circulated autoclave (M/K System Inc.) in triplicate. The amount of $450 \mathrm{~g}$ oven-dried equivalent chips per cook were pulped using conditions : varied active alkali as $\mathrm{Na}_{2} \mathrm{O}$ (15\%,16\%, 17\%, 18\%); $25 \%$ sulfidity; $4: 1$ liquor/wood ratio, $170^{\circ} \mathrm{C}$ cooking temperature, $120 \mathrm{~min}$ to cooking temperature and $90 \mathrm{~min}$ at cooking temperature. The pulping condition of PM chips was similar to AN chips except for an active alkali level of only $20 \%$ rather than multiple amounts. After digestion, the black liquor was removed by washing and the cooked pulps were screened to separate the fibers from the rejects. The screened yield (through a 60-mesh screen onto a 80-mesh) and reject were counted as a percentage of their oven-dried mass of chips. The pulps were then disintegrated in a laboratory-type pulp mixer. Kappa number was measured according to SNI 140494-89.

\section{Pulp Beating}

The pulp freeness was determined according to the Canadian Standard Freeness (CSF) method (TAPPI standard method T-227 om-92). The unbleached pine pulps at a consistency of $3 \%$ were beaten to 200 300 CSF and 300 400 CSF in PFI mill no. 236 according to TAPPI T200. The unbleached AN pulps were blended with PM pulp in four mixing ratios $(100: 0,90: 10,80: 20,70: 30)$ by weighing their appropriate amounts. The mixtures then were subjected to beating to achieve a freeness of 200 300 CSF. The beating duration to obtain 250 CSF was calculated by intrapolation on the basis of the intial degree of freeness.

\section{Physical Properties of Pulp}

Handsheets in $60 \mathrm{~g} / \mathrm{m}^{2}$ basis weights were prepared from beaten pulps using a sheet former (SNI 14-04891989). Pulp handsheets at each level of mixing ratio $(0 \%$; $10 \% ; 20 \% ; 30 \%$ addition of PM pulps) as well as different kappa numbers of AN pulps were made. Handsheets were kept overnight and allowed to condition at $23 \pm 1^{\circ} \mathrm{C}$ and 50 $\pm 2 \%$ relative humidity before testing (SNI 14-0402-1989). The tensile, bursting, and tearing strength, fold number, as well as thickness values were obtained according to SNI 140437-1989, SNI 14-0493-1989, SNI-14-0436-1989, SNI 140491-1989, and SNI 14-0439-1989, respectively. The brightness and opacity of handsheets were also measured using a Photovolt Reflectometer that conformed to SNI 140495-1989 and SNI 14-0438-1989, respectively.

\section{Measurement of Fiber Dimension}

A portion of beaten pulp of single species was measured for its fiber dimensions by microscopic image. Fiber diameter and length was measured and recorded with a light microscope with a digital camera (Olympus BX 51; Olympus Coorporation; Japan). Furthermore, imageanalysis software (Image pro Plus) was utilized to measure the fiber dimension. Simple fractionation was based on the results of fiber dimension measurements. The fractionation resulted in the composition of intact fibers, fiber fragment, and fines with 5 specimens classified per single species.

\section{Results and Discussion}

\section{Yield and Kappa Number}

Pulping was carried out for two species i.e. PM for long-fiber source and AN for short-fiber. The yield and kappa number determination is presented in Table 1. The PM pulping was done by high active alkali concentration $(20 \%)$ to obtain a kappa number below 20 . The yield obtained was in the normal range of hardwood for commercial pulping but lower than previously reported (Lukmandaru et al. 2004). On the contrary, the kappa number of AN pulp was still high (32 35) although the active alkali used was $18 \%$. In general, the increase of active alkali levels up to $16 \%$ was followed by the increase of screened yield (39 48\%) and decrease of the rejects $(11 \sim 1 \%)$ of AN pulps. With regard to total yield levels (46 51\%), the increase started at the active alkali of $17 \%$ which is assumed to be the beginning of intensive degradation of polysaccharides.

The kappa number indicates the residual lignin in pulp as well as the degree of delignification achieved during pulping. The comparatively high kappa number of AN pulps could be ascribed to higher specific gravity of the wood (0.86) compared to those of other Acacia species (Haroen and Dimyati 2006; Jahan et al. 2008; Yahya et al. 2010). It assumed that high density caused less intensive liquor penetration. The levels of yield and kappa number obtained here was in the range of the values of earlier studies on AN kraft pulps (Khristova et al. 1997; Lukmandaru et al. 2002; Onuorah et al. 2014).

Table 1. Yield and kappa number of kraft cooking of Pinus merkusi and Acacia nilotica chips.

\begin{tabular}{lcrcc}
\hline Measurement & Screened yield $(\%)$ & Reject $(\%)$ & Total yield $(\%)$ & Kappa number \\
\hline Pine & $46.47(1.35)$ & $2.25(0.74)$ & $48.73(2.10)$ & $13.1(0.2)$ \\
AN-AA15\% & $39.20(0.56)$ & $11.07(3.75)$ & $50.27(4.32)$ & $35.9(1.8)$ \\
AN-AA16\% & $48.38(2.06)$ & $2.68(0.40)$ & $51.06(2.46)$ & $34.0(0.8)$ \\
AN-AA17\% & $47.24(2.77)$ & $2.33(1.82)$ & $49.58(4.59)$ & $34.2(0.7)$ \\
AN-AA18\% & $45.12(2.98)$ & $1.02(0.45)$ & $46.15(3.44)$ & $32.5(0.2)$ \\
\hline
\end{tabular}

Remark : $\mathrm{AN}=$ Acacia nilotica, $\mathrm{AA}=$ active alkali concentration. Mean of 3 measurements with standard deviation on parentheses. 


\section{Physical Properties of Pine Pulp}

Beating or refining is the crucial mechanical treatment applied to pulp before paper making (Walker 2006). It causes fiber conformability and increases the bonding area in paper (Manfredi 2006; Corson 1980). However, high intensity beating causes shortening of the fiber length formation of fines, and decreased fiber strength (Casey 1981; Page 1989). A beating degree between 300 and 450 $\mathrm{ml} \mathrm{CSF}$ is a typical, acceptable value for papermaking (Shakhes et al. 2010). Further beating of pine pulp causes a considerable decrease both in the tear index and the apparent specific volume (Danielewicz and SurmaŚlusarska 2004). To discover the effects of beating, PM pulps were beaten to 200 300 CSF (heavy-beating) and 300 400 CSF (moderate-beating). Pulp handsheets at each level were made and the physical properties were examined (Table 2). The results demonstrated that heavy-beating reduced the strengths considerably, in particular, tear index (reduced to $71.4 \%$ ) and fold number (reduced to $93.9 \%$ ). On the other hand, an increase was only found in brightness. Thus, the magnitude of reduction was considered to be sufficient to evaluate the pulp mixtures for the next step.

Table 2. Physical properties of Pinus merkusii pulp in different beating degrees.

\begin{tabular}{|c|c|c|c|}
\hline Measurement & $300 \sim 400 \mathrm{CSF}$ & 200 300 CSF & Percent reduction (\%) \\
\hline Thickness $\left(\times 10^{-3}\right) \mathrm{cm}$ & 205.80 & 136.25 & 33.7 \\
\hline Brightness (\%) & 20.7 & 24.3 & -17.3 \\
\hline Opacity $(\%)$ & 91.7 & 87.9 & 4.1 \\
\hline Tear index $\left(\mathrm{Nm} \cdot \mathrm{m}^{2} \cdot \mathrm{g}^{-1}\right)$ & 49.19 & 14.04 & 71.4 \\
\hline Tensile index $\left(\mathrm{Nm} . \mathrm{g}^{-1}\right)$ & 41.15 & 35.62 & 13.4 \\
\hline Burst index $\left(\mathrm{kPa} \cdot \mathrm{m}^{2} \cdot \mathrm{g}^{-1}\right)$ & 4.15 & 3.72 & 10.3 \\
\hline Fold number & 719.6 & 43.6 & 93.9 \\
\hline
\end{tabular}

\section{Duration of Beating}

Beatability of pulps, expressed by freeness, indicates the energy consumption of mills and mostly is affected by the chemical composition of pulps (Gulsoy and Tufek 2013). Furthermore, beatability has a significant role in affecting drainage characteristics of paper machines. AN pulps with varied kappa number then were mixed with different ratios of PM pulps on the basis of their weights. The pulps were then beaten to 200 300 CSF. The initial beating degree of unmixed AN pulps ranged from 740 to 760 CSF whereas PM pulps were 730 740 CSF. The linearly intrapolated beating time to achieve $250 \mathrm{CSF}$ was calculated both for mixed and unmixed pulps (Table 3). Judging by the kappa number, it was noticed that the more intensively-cooked PM pulps required a longer beating duration $(23.5$ mins $)$ than the AM pulps (11 13 mins). This was probably due to the longer and thicker fiber of PM pulps. This approach has previously been put forward in a study of kenaf (Shakhes et al. 2010). In general, the addition of PM pulps in amounts of $10 \%$ and $20 \%$ increased the beating duration whereas the amount of $30 \%$ decreased the beating duration. At this time, the explanation for such a finding remains uncertain. This finding may be due to a complex interaction of the low kappa number and high fiber dimension of PM pulps against the AN pulps. Results also showed that the more delignified AN pulp (kappa number 32.5 and 34.0 ) did not show an increasing beating duration with $10 \%$ addition of PM pulps. These differences may be due to the lower residual lignin content which results in easier beating. Previous study demonstrated that the relationship between beating time and the kappa number was positively linear (Gulsoy and Tufek 2013).

Table 3. Beating duration to 250 CSF of mixture pulp of Pinus merkusii and Acacia nilotica

\begin{tabular}{|c|c|c|}
\hline Pulp material & Initial freeness (CSF) & Duration to 250 CSF (min) \\
\hline Pine $-100 \%$ & $730 \sim 740$ & 23.5 \\
\hline AN1 - pine $0 \%$ & $740 \sim 755$ & 12.3 \\
\hline AN1 - pine $10 \%$ & $725 \sim 735$ & 17.3 \\
\hline AN1 - pine $20 \%$ & $730 \sim 740$ & 11.1 \\
\hline AN1 - pine $30 \%$ & $735 \sim 745$ & 10.1 \\
\hline AN2 - pine $0 \%$ & $745 \sim 755$ & 11.3 \\
\hline AN2 - pine $10 \%$ & $740 \sim 750$ & 17.5 \\
\hline AN2 - pine $20 \%$ & $735 \sim 765$ & 12.1 \\
\hline AN2 - pine $30 \%$ & $730 \sim 735$ & 11.2 \\
\hline AN3 - pine 0\% & $740 \sim 745$ & 12.5 \\
\hline AN3 - pine $10 \%$ & $725 \sim 750$ & 13.3 \\
\hline AN3 - pine $20 \%$ & $750 \sim 755$ & 10.5 \\
\hline AN3 - pine $30 \%$ & $750 \sim 755$ & 11.7 \\
\hline AN4 - pine $0 \%$ & $745 \sim 760$ & 11.9 \\
\hline AN4 - pine $10 \%$ & $745 \sim 760$ & 12.7 \\
\hline AN4 - pine $20 \%$ & $735 \sim 755$ & 12.2 \\
\hline AN4 - pine $30 \%$ & $735 \sim 740$ & 11.6 \\
\hline
\end{tabular}

Remark : AN1, AN2, AN3, and AN4 are Acacia nilotica pulps with kappa number 35.9; 34.0; 34.2; and 32.5, respectively. 


\section{Fiber Dimension after Beating}

Samples of unmixed pulps after beating were measured for their fiber dimension. The microscopic and measurement results are described in Table 3 and Fig. 1. As expected, the intact PM fibers were longer (1.956 4.577 $\mu \mathrm{m})$ and wider in diameter compared to those AN fibers $(1.160 \sim 1.307 \mu \mathrm{m})$. This trend also applied to slenderness ratio (47 82) causing higher values of tear strength of PM pulps. Previous data for PM showed that the values of fiber length, fiber diameter, and slenderness ratio before beating were $4.771 \mu \mathrm{m}, 47 \mu \mathrm{m}$, and 115, respectively (Pasaribu and Roliadi 1990) whereas for AN were $1.133 \mu \mathrm{m}, 18 \mu \mathrm{m}$, and 63 (Onuorah et al. 2014).

In unbeaten chemical softwood pulps, the amount of fiber fraction is $95 \sim 100 \%$ (Paavilainen 1990). The fiber fraction is mainly composed of intact fibers with different lengths. Chemical pulps generate primary fines (0 5\%) and consist of parenchyma cells, fiber pores, and short cut fibers whereas secondary fines formed after refining consist of flexible fibrils, fiber wall fragments, and short cut fibers (Paavilainen 1990; Waterhouse et al. 1993). It can bee seen that there was an extensive fiber shortening of the PM pulp during heavy beating. Furthermore, fiber conditions can be categorized as intact fibers, fiber fragments, and fines (Fig. 1). By simple fractionation through the microscopic images, the portions of each part were calculated. To facilitate the interpretations, the PM pulps were divided into 3 dimensions of fiber fragments (Table 4). The intact fibers of PM showed a small percentage $(0 \sim 12 \%)$ as the intact $A N$ fibers had considerable portions (52 72\%). This result was probably due to the combination of the low kappa number of PM pulps (13.1) and high refiner energy. As this method only gave a rough description, it is necessary to employ fiber classifier machine for more accurate data. Furthermore, the actual fiber composition remained unknown as the fiber dimension of mixture pulps after beating were not measured in this experiment. The beating properties of a pulp mixture might behave differently from a single fiber pulp.
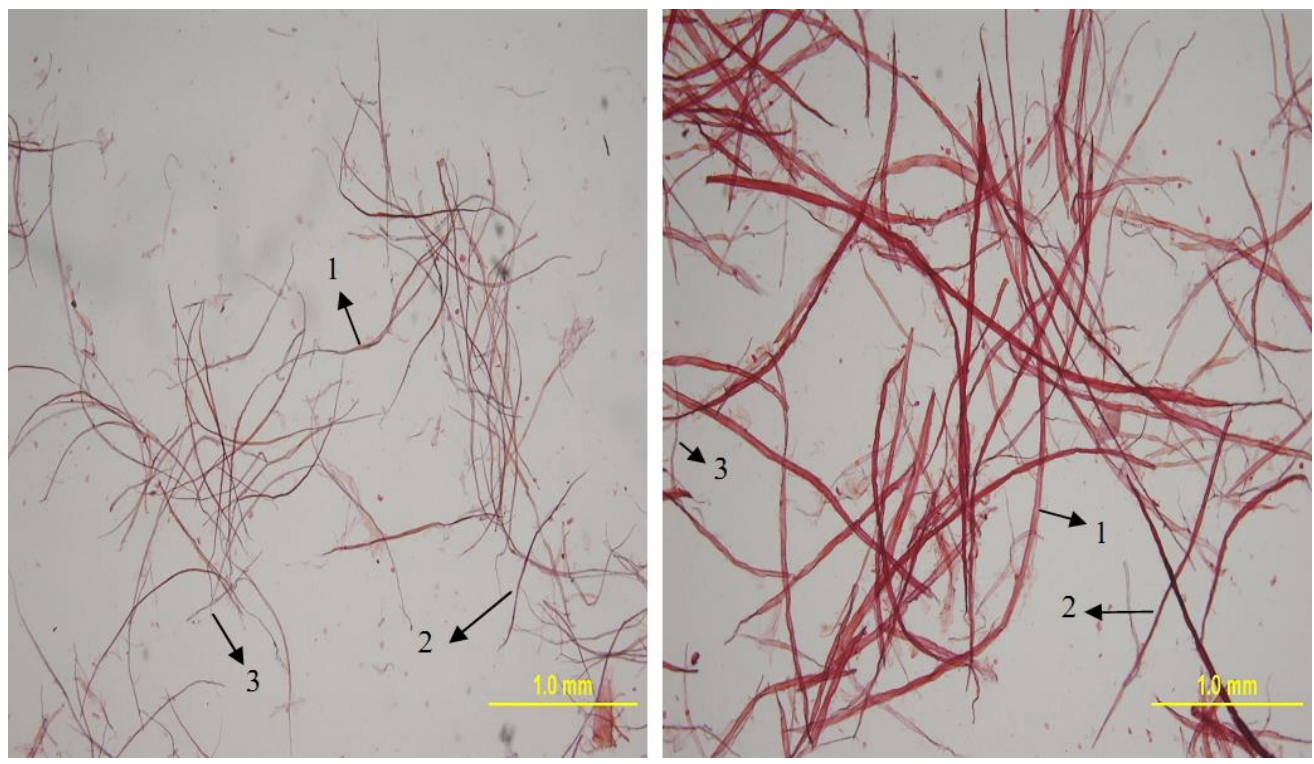

Figure 1. Microscopic images of Acacia nilotica (a) and Pinus merkusii fibers after beating (200 300 CSF). Remark 1 = intact fibers, $2=$ fiber fragments, $3=$ fines.

Table 4. Fractionation of Acacia nilotica (a) and Pinus merkusii fibers after beating (200 300 CSF) based on microscopic images.

\begin{tabular}{lcccc}
\hline Species & Length $(\mu \mathrm{m})$ & Width $(\mu \mathrm{m})$ & Slenderness ratio & Percentage $(\%)$ \\
\hline Nilotica pulp & & & & \\
- Intact fibers & $1.160-1.307$ & $18-22$ & $18-64$ & $52-72$ \\
- Fiber fragments & $478-628$ & $18-21$ & $26-30$ & $25-42$ \\
- Fines & $<300$ & $<15$ & $<13$ & $4-8$ \\
& & & & \\
Pine pulp & & & $47-82$ & $0-12$ \\
- Intact fibers & $1.956-4.577$ & $41-56$ & $33-44$ & $31-46$ \\
- Fiber fragments - long & $1.364-1.983$ & $41-46$ & $36-40$ & $18-32$ \\
- Fiber fragments - medium & $878-1.094$ & $24-28$ & $29-34$ & $16-32$ \\
- Fiber fragments - short & $522-834$ & $18-25$ & $<20$ & $6-14$ \\
- Fines & $<300$ & $<15$ & & \\
\hline
\end{tabular}




\section{Physical Properties of Mixtures Pulp}

The strength and other properties of hand sheet made from mixed beating of pulps are either better or comparable than those of separately beaten pulps (Chauhan et al. 2011). After beating, the handsheets were formed at a target basis weight $60 \sim 70 \mathrm{~g} / \mathrm{cm}^{2}$ and were tested. The results of thickness, brightness, and opacity measurements are displayed in Fig. 2. The thickness $\left(136.2 \times 10^{-3} \mathrm{~cm}\right)$ and brightness $(22.53 \%)$ values of unmixed PM pulps were higher but lower in opacity (87.97\%) than those of unmixed AN pulps. It is expected that fines fraction would increase the opacity and decrease fiber density (Görres et al. 2001). In general, an increase in PM pulp amounts resulted in an increase in brightness and decrease in thickness. It appeared that thickness and brighness behaved additively as a function of their mixing ratio. This can be explained by considering that extra fines tend to compact the paper sheet but reduce its density and thickness. However, no clear trend was observed with regard to opacity. Perhaps this result came from the fact more fiber fragments will in turn give a more open structure, albeit to a small degree, and consequently reduce light scattering. On the basis of kappa number, brightness decreased with increasing kappa number (Fig. 2c). The AN pulps with kappa number 34.2 tended to give the highest values on handsheet thickness (Fig. 2a).

Remarkable differences were found between unmixed and $30 \%$ ratio of PM pulps. On the other hand, the addition of $10 \%$ and $20 \%$ showed a fluctuating curve for brightness and thickness levels. The thickness decreased $3.69 \sim 11.19 \%$ from the initial values $\left(156 \times 10^{-3} \mathrm{~cm} \sim 193 \mathrm{x}\right.$ $10^{-3} \mathrm{~cm}$ ) after the $30 \%$ addition of PM pulps. The same treatment could increase brightness $4.1 \sim 11.5 \%$ on the basis of unmixed AN pulps (15.7 17.2\%). Although the increase percentage was small $(0.1 \sim 0.8 \%)$, it was found that the $20 \%$ ratio of PM pulps achieved the highest opacity based on initial values (98.4 99.5\%) with the exception of AN pulps with kappa number of 32.5 . Furthermore, pulps with a high kappa number (35.9) tended to have low brightness.
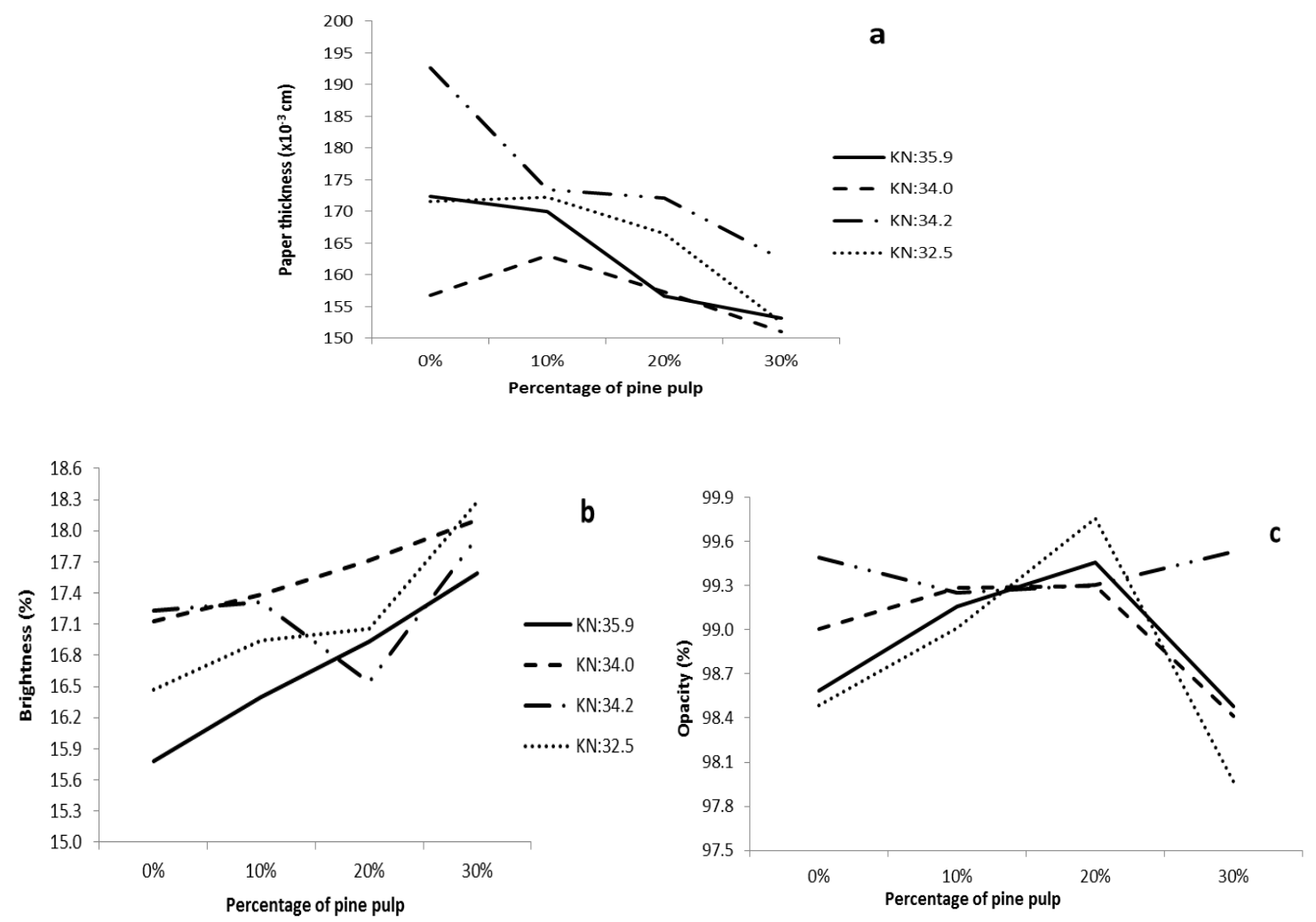

Figure 2. Measurements of handsheets thickness, brightness, and opacity of Acacia nilotica and Pinus merkusii pulps. Remark : KN = kappa number. 

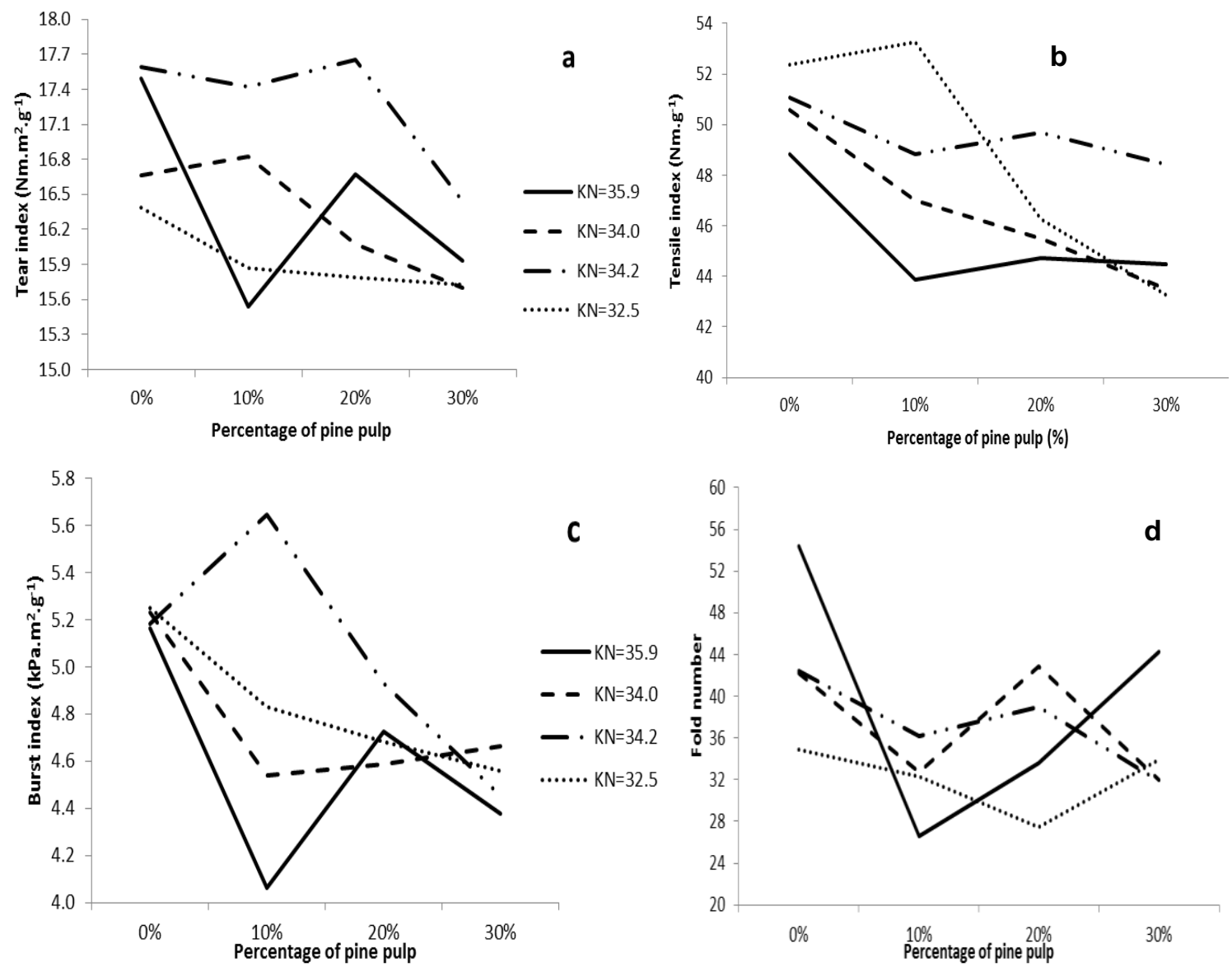

Figure 3. Measurements of strength properties of Acacia nilotica (a) and Pinus merkusii pulps. Remark : KN = kappa number

Several previous studies related to mixed pulping of several hardwood and softwood species were reported (Danielewicz and Surma-Ślusarska 2004; Chauhan et al. 2011; Gulsoy and Tufek 2013; Nordström and Hermansson 2017) as well as studies on PM pulp mixing in Indonesia (Yasin et al. 1984; Rismijana et al. 1992). These studies mostly discussed the enhancement of strength properties after long-fiber addition. The mixture of different kraft pulps of AN and PM, could be assumed to behave in a nonlinear manner as a function of the mixing ratio of the pulps as their properties were not similar. The determination of pulp strength is presented in Fig. 3. In general, the strengths decreased as a result of adding PM pulps whereas no distinct pattern was found with increasing kappa number.

The tear index of unmixed PM pulps was 14.24 $\mathrm{Nm} \cdot \mathrm{m}^{2} \cdot \mathrm{g}^{-1}$ compared to $16.3 \mathrm{Nm} \cdot \mathrm{m}^{2} \cdot \mathrm{g}^{-1} \sim 17.5 \mathrm{Nm} \cdot \mathrm{m}^{2} \cdot \mathrm{g}^{-1}$ of unmixed AN pulps (Fig. 3a). PM pulp could reduce the strength of the paper sheets $3.0 \sim 8.9 \%$ based on its initial values by $30 \%$ ratio whereas the $10 \%$ or $20 \%$ ratios showed more varied patterns. The highest values of tear index $\left(17.65 \mathrm{Nm} \cdot \mathrm{m}^{2} \cdot \mathrm{g}^{-1}\right)$ of unmixed AN pulps were measured in $30 \%$ addition of PM pulp samples (kappa number $=34.2$ ). The fold numbers of unmixed AN pulps ranged from 34 55 (Fig. 3d) whereas the average value of unmixed PM pulps were 43. Based on the initial values, the $30 \%$ ratio of PM pulps decreased the strength by $2.8 \%$ to $24.7 \%$. Except for AN pulps with a kappa number of 34.0 , the fold number of handsheets with $10 \%$ ratio had higher values than those of $20 \%$ ratio of PM pulps.

The unmixed AN pulps had a tensile index of 48.81 Nm.g-1 52.37 Nm.g-1 (Fig. 3b); as for PM pulp, the tensile index was $37.47 \mathrm{Nm} \cdot \mathrm{g}^{-1}$. A reduction of strength (8.8 17.3\%) was observed for $30 \%$ ratio of PM pulps. A strength enhancement $\left(53.27 \mathrm{Nm}^{-1} \mathrm{~g}^{-1}\right)$ equal to $1.71 \%$ of initial value was found in the AN samples (kappa number = $32.5)$ with $10 \%$ ratio of PM pulps. PM pulps lowered the burst index $10.1-15.1 \%$ of its unmixed AN pulps (5.16 kPa. $\left.\mathrm{m}^{2} . \mathrm{g}^{-1} \sim 5.25 \mathrm{kPa} \cdot \mathrm{m}^{2} . \mathrm{g}^{-1}\right)$ by $30 \%$ addition. A burst index increase of $9.0 \%\left(5.65 \mathrm{kPa} \cdot \mathrm{m}^{2} . \mathrm{g}^{-1}\right)$ was observed only in the AN samples (kappa number 34.2 ) as a result of adding $10 \%$ PM pulps. By comparison, unmixed PM pulps had burst index of $3.86 \mathrm{kPa} \cdot \mathrm{m}^{2} \cdot \mathrm{g}^{-1}$.

The sum of the fiber strength and the fiber network properties result in the strength properties of a fiber network. Thus, fiber damage and fiber deformations would decrease the initial strength. Of all strength properties measured, fold number was mostly reduced (2.8 24.7\%) by the blend composition but there was a less pronounced decrease in tear index (3.0 8.9\%). Theoretically, tearing resistance was affected by total number of fibers participating in the sheet 
rupture, fiber length and number and strength of the fiber to fiber bond (Casey 1981). It was thought that the shortening of fibers did not substantially reduce the tear strength as the cut fiber of PM were mostly similar in length to AN fibers (Table 4). The strength of AN fibers slightly improved at first (10\% or $20 \%$ ratio of PM pulps) in some samples, but then decreased at $30 \%$ ratio. At small share, fines fraction probably would provide the needed bonding. Pulp sheets prepared from material with a small degree of damaged fibers (dislocated fiber walls, curls and kinks) will have improved stretch and tear indices compared with pulp sheets prepared from fibers lacking deformations (Kibblewhite 1976; Page et al. 1985). The strength reduction at $30 \%$ ratio of PM pulp might be caused by extra fines would separate fibers from each other thus starting to break their unified network. Further investigation is required to determine whether the presence of fines or other kinds of fiber damages will affect the strength reduction.

\section{Conclusions}

Heavy-beating caused more fines and extensive fiber shortening of PM as observed from microscopy images. However, adding PM pulps to AN pulp did not affect the beating duration considerably. The effects on thickness, paper strength, and optical properties of blending pine and AN kraft pulps during beating in various proportions have been examined. The kappa number of AN pulps did not show a clear correlation with the physical properties of the sheets. Although it was not applied in all samples, the $10 \%$ or $20 \%$ addition of PM pulps caused handsheet opacity and strengths to be increased in varying degrees. The effect of adding different proportions of PM pulps improved brighness but reduced thickness with increasing amounts of PM pulps. The strengths generally decreased in varying degrees at $30 \%$ ratio of $\mathrm{PM}$ pulps. Tear index, however, was less affected than the other measured strengths. The results of this study suggest that the high proportion of fines generated during heavy-beating causes poor bonding.

\section{Acknowledgements}

We thank Perum Perhutani KPH Kedu Selatan and Baluran National Park for providing research materials.

\section{References}

Azeez, M.A.; J.E. Andrew; B.B. Sithole. 2016. Preliminary Investigation of Nigerian Gmelina arborea and Bambusa vulgaris for Pulp and Paper Production. Maderas. Ciencia y tecnología 18(1): 65-78.

Casey, J.P. 1981. Pulp and Paper: Chemistry and Chemical Technology. Volume 3. John Wiley \& Sons, New York, NY.

Chauhan, V.S.; N. Kumar; M. Kumar; S.K. Chakrabarti; S.K. Thapar. 2011. Effect of Separate and Mixed Refining of Hardwood and Softwood Pulps on Paper Properties. Journal of Korea TAPPI 43(4): 1-8.

Corson, S. 1980. Fiber and Fines Fractions Influence Strength of TMP. Pulp and Paper Magazine of Canada 81(5): 69-76.

Danielewicz, D.; B. Surma-Ślusarska. 2004. Effect of Birch and Pine Fiber Content and Degree of Beating on the Properties of Bleached Sulphate Pulps. Fibers \& Textiles in Eastern Europe 12(4): 73-77.

Görres, J.; R. Amiri; D. McDonald. 2001. The Specific Pore Volume of Multi-Planar Webs: The Role of The Short and Long Fiber Fractions. 12th Fundamental Research Symposium, Oxford, September 2001. pp 1371-1383.

Gulsoy S.K.; T. Stufek. 2013. Effect of Chip Mixing Ratio of Pinus pinaster and Populus tremula on Kraft Pulp and Paper Properties. Industrial and Engineering Chemistry Research 52: 2304-2308.

Kibblewhite, R.P. 1976. Fractures and Dislocations in The Walls of Kraft and Bisulphite Pulp Fibers. Cellulose Chemistry and Technology 10(4): 497-503.

Haroen, W.K.; F. Dimyati. 2006. Sifat Kayu, Teras, dan Gubal Acacia mangium terhadap Karakteristik Pulp. Berita Selulosa 41: 1-7.

Jahan, M.S.; R. Sabina; A. Rubaiyat. 2008. Alkaline Pulping and Bleaching of Acacia auriculiformis Grown in Bangladesh. Turkish Journal of Agriculture and Forestry 32: 339-347.

Khristova, P.; L. Karar. 1999. Soda-anthraquinone Pulp from Three Acacia nilotica subspecies. Bioresource Technology 68: 209-213.

Lukmandaru, G.; R.M. Siagian; S.N. Marsoem. 2002. Kualitas Kayu Nilotika (Acacia nilotica) sebagai Bahan Baku Pulp. Prosiding Seminar Nasional MAPEKI V. Puslitbang Bogor. pp 397-402.

Lukmandaru, G.; T. Listyanto; S.N. Marsoem; A. Setyawan; A. Fernandes. 2004. Studi Pendahuluan Pulping Kayu Pinus (Pinus merkusii Jungh. et de Vriese) dengan Proses Alkalin Etanol. Prosiding Seminar Nasional MAPEKI VII, Makassar. pp B157-B161.

Manfredi, V. 2006. Evaluation of Refining Strategies for Combined use of Softwood and Eucalyptus Pulps in Papermaking. Pan Pacific Conference Advance in Pulp and Paper Sciences \& Technologies. pp 37-42.

Nordström, B.; L. Hermansson. 2017. Effect of the Ratio of Softwood Kraft Pulp to Recycled Pulp on Formation and Strength Efficiency in Twin-wire Roll Forming. Nordic Pulp \& Paper Research Journal 32(2): 229236.

Onuorah; E. Onyekewe; Ekesiobi; A. Ignatius; NLC Elias. 2014. The Potentials of Acacia nilotica var. Tomentosa (Benth.) A.F. Hill; Trema orientalis (Linn.) Blume and Raphia hookeri Mann. \& Wendland for Pulp and Paper Making. International Journal of Agriculture and Biosciences 3(6): 271-277. 
Paavilainen, L. 1990. Importance of Particle Size - Fiber Length and Fines - For the Characterization of Softwood Kraft Pulp. Paperi Puu 72(5): 516-526.

Page, D.H. 1989. The Beating of Chemical Pulps - The Action and the Effects. In: Papermaking Raw Materials: Transactions of the Ninth Fundamental Research Symposium Volume 1. London. pp.1-37.

Page, D.H.; R.S. Seth; B.D. Jordan; M.C. Barbe. 1985. Curl, Crimps, Kinks and Microcompressions in Pulp Fibers - Their Origin, Measurement and Significance. In: Papermaking Raw Materials.Transactions of the Eigth Fundamental Research Symposium, Vol. 1. Oxford, Sept., 1985. pp. 183-227.

Pasaribu, R.A.; H. Roliadi. 1990. Komponen Kimia dan Beberapa Dimensi Serat Beberapa Jenis yang Berasal dari Hutan Tanaman dan Hutan Alam. Badan Litbang Kehutanan Bogor.

Rismijana, J.; T.P. Basuki; G. Ibnusantosa. 1992. Percobaan Pembuatan Pulp Fluff. Berita Selulosa 28(3-4): 86-89.

Shakhes, J.; M.R. Dehghani-Firouzabadi; P. RezayatiCharani; F. Zeinaly. 2010. Evaluation of Harvesting Time Effects and Cultivars of Kenaf on Papermaking. BioResources 5(2): 1268-1280.

Shmulsky, R.; P.D. Jones. 2011. Forest Products and Wood Science: An Introduction, Sixth Edition. John Wiley \& Sons, Inc.

Walker, J.C.F. 2006. Primary Wood Processing Principles and Practice.2nd edition. Springer, Dordrecht, The Netherlands.
Waterhouse, J.; K. Omori. 1993. The Effects of Recycling on the Fines Contribution to Selected Paper Properties. Products of Papermaking. Transactions of the 10th Fundamental Research Symposium 1993. PIRA, Oxford, UK, September 20-24, 1993, Vol 2. pp 12611292.

Yahya, R.; J. Sugiyama; D. Silsia; J. Gril. 2010. Some Anatomical Features of an Acacia hybrid, A.mangium, and $A$. auriculiformis Grown in Indonesia with Regard to Pulp Yield and Paper Strength. Journal of Tropical Forest Science 22: 343-351.

Yasin, F.; A. Salihima; Pramono. 1984. Serat Rayon dari Campuran Pulp Acacia auriculiformis dengan Pinus merkusii. Berita Selulosa 20(3): 77-82.

Ganis Lukmandaru* and Fajar Setiaji

Department of Forest Product Technology, Faculty of Forestry, Universitas Gadjah Mada Jl. Agro No. 1, Bulaksumur, Sleman, Indonesia, 55281

${ }^{*}$ Corresponding author

Tel. : : +62-274-512203

Fax. : +62-274-550541

E-mail : glukmandaru@ugm.ac.id

Rena M. Siagian

Forest Products Research and Development Center Jl. Gunung Batu 5, Bogor, Indonesia, 16118 